\title{
The control of the schistosome-transmitting snail Biomphalaria glabrata by the plant Molluscicide Euphorbia splendens var. hislopii (syn milli Des. Moul): a longitudinal field study in an endemic area in Brazil
}

\author{
Virgínia T. Schall a,*, Maurício C. Vasconcellos a, Roberto S. Rocha ${ }^{\mathrm{b}}$, \\ Cecília P. Souza ${ }^{\mathrm{b}}$, Nelymar M. Mendes ${ }^{\mathrm{b}}$ \\ a Departamento de Biologia, Instituto Oswaldo Cruz, Rio de Janeiro, RJ, Brazil

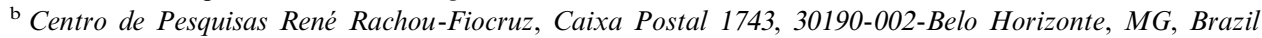

Received 7 January 1999; received in revised form 20 December 2000; accepted 8 January 2001

\begin{abstract}
Under laboratory conditions, latex from Euphorbia splendens has shown promise as a plant molluscicide for control of Biomphalaria species, intermediate hosts for Schistosoma mansoni. The purpose of this study was to evaluate its efficiency under field conditions. Application of filtered latex at $12 \mathrm{ppm}$ to one stream in an endemic rural area in Minas Gerais state, Brazil, in September 1995, did result in a reduction in snail density as compared to an untreated stream but the snail population recovered quickly. However, two applications with a two-week interval of unfiltered E. splendens latex at $5 \mathrm{ppm}$ in November 1996 in the same stream resulted in complete disappearance of $B$. glabrata and snails did not reappear until the 14th month after the applications. In the control stream, without treatment, the snails were found during all months. Laboratory studies confirmed that unfiltered latex is a more potent molluscicide than filtered latex. Considering the advantages of the latex such as its low toxicity to other aquatic animals and its photobiodegradability, as well as the simple method of application, this natural product is promising as an effective molluscicide. (C) 2001 Elsevier Science B.V. All rights reserved.
\end{abstract}

Keywords: Schistosomiasis; Plant molluscicide; Biomphalaria glabrata; Euphorbia splendens; Brazil

\section{Introduction}

Integrated schistosomiasis control programmes are recommended by WHO (1994), and snail con-

\footnotetext{
* Corresponding author. Fax: + 55-31-2953115.

E-mail address: vtschall@cpqrr.fiocruz.br (V.T. Schall).
}

trol is an important preventive strategy associated with treatment of ill people, together with environmental and socio-economic improvements and health education with community participation. Although chemical molluscicides are the most used approach of snail control (WHO, 1994), the majority of studies have demonstrated rapid re- 
colonization of the transmission sites by the intermediate hosts (Pieri et al., 1995; Khallaayoune et al., 1998). In Brazil, the use of niclosamide is frequent and the recolonization requires frequent, or at least, monthly applications (Pieri et al., 1995), which are expensive and operationally impossible. Other side effects are reported in literature such as the lethal action of niclosamide on non target organisms, such as Amphibia, fish and aquatic plants (Andrews et al., 1983). For these reasons, there are a lot of studies in order to develop alternative measures of snail control. One of them is based on the possibility to use a plant or a plant derived product being of low toxicity for the environment and other organisms as well as being effective as a molluscicide.

Previous studies demonstrated the lethal action of the latex of Euphorbia splendens var. hislopii (Crown of Christ) on Biomphalaria glabrata, $B$. tenagophila, B. straminea (snail hosts of Schistosoma mansoni in Brazil), B. pfeifferi (intermediate host of $S$. mansoni in Africa) and Bulinus sp. (snail host of $S$. haematobium in Africa). In these studies $\mathrm{LD}_{90}$ values ranged from 0.13 to $4.0 \mathrm{ppm}$, depending on the species tested (Vasconcellos and Schall, 1986; Schall et al., 1998).

The phytochemical fractionation of the latex revealed eight substances derived from the active fraction. One of them, milliamine L, was lethal $\left(\mathrm{LD}_{90}\right)$ for snails at a concentration of $0.01 \mathrm{ppm}$ (Zani et al., 1993).

Extensive toxicological testing indicated that the recommended field dosage is not harmful to non target organisms (Schall et al., 1998). Latex showed only little variation in potency over season and geographic area of harvesting (Schall et al., 1992). Other tests have demonstrated that the molluscicidal activity of the natural latex remained unchanged after storage for 124 days in a closed assay tube at room temperature and for 736 days in a closed bottle (lyophilized latex) in a refrigerator at $10-12^{\circ} \mathrm{C}$ (Schall et al., 1992). Field tests with the natural latex in lentic and lotic environments killed $100 \%$ of $B$. glabrata and $B$. tenagophila at concentrations of 5 and $12 \mathrm{ppm}$, respectively (Baptista et al., 1992, 1994; Mendes et al., 1992, 1997).
The present study has the objective to evaluate the potential effect of $E$. splendens latex on intermediate host snails in the field and to follow recolonization of treated sites by these snails.

\section{Material and methods}

\subsection{The study area}

The field study was conducted at the rural area of Comercinho, a municipality located in Vale do Jequitinhonha, at the northeast region of the State of Minas Gerais, $713 \mathrm{~km}$ far from Belo Horizonte city. It is an hyperendemic area for schistosomiasis, whose prevalence in the urban area was in the order of $70 \%$ in 1981 , prior to initiating a large scale control programme. A later survey showed that the prevalence of the disease had dropped to 13\% (Rocha, 1995).

Comercinho has 10000 inhabitants, but only 2000 of them live in urban settings. The remaining population is distributed in 66 rural communities where sewage systems are unexistent. In the urban area, $87.6 \%$ of the dwellings are connected to waterworks.

\subsection{Description of the streams and snail sampling methods}

The study was carried out in two streams. One of them, Córrego Barrocão, the experimental, was selected for not posing any risk to people through contact with the latex solution in water. While latex was applied in the experimental stream, no molluscicide was applied in the stream Córrego Areia (control). Density of B. glabrata was determined monthly from May 1995 to February 1997 and every 4 months from February 1997 to January 1998 . The density of snails was evaluated by taking 10-dips with a $20 \mathrm{~cm}$ diameter scoop net at five pre-selected sites at $50 \mathrm{~m}$ intervals. The snails collected were sent to a laboratory to be counted, measured, examined for schistosome infections and then disposed of. Presence or absence of other animals that were found in the stream, such as fishes and other mollusc species was noted. This observation was not quantitative but only a 
register of the absence or presence of these animals. Ambient and stream water temperature and the rainfall index were measured monthly in parallel to the evaluation of snails density.

\subsection{Extraction of the latex and molluscicide application}

The latex was obtained by collecting drops from cuts on the plant stem in E. splendens grown in the gardens surrounding the Magalhães Pinto Stadium in Belo Horizonte, MG, Brazil. Aqueous solutions were applied with a watering can in the headwaters of the experimental stream. Safety instructions provided by McCullough (1992) were followed at all stages of the application in order to prevent any direct contact with the skin and the eyes of the researchers. In all tests, $48 \mathrm{~h}$ after applying the latex, snails were collected by scoopfuls and caught from sieves (a kind of trap, like a Surber Sampler) placed at five different sites of the streams (50 m apart) and sent to the laboratory where they were placed under observation and examined for three days to evaluate their mortality.

One application of $12 \mathrm{ppm}$ of filtered latex was made in September 95. The filtered aqueous solution of the latex was obtained by filtering it through a funnel covered with a filter paper, so as to remove the plant impurity. In November 1996 two applications of $5 \mathrm{ppm}$ of unfiltered latex were made with an interval of 15 days.

\subsection{Laboratory tests of the latex solutions}

Laboratory tests were performed at the Malacology Laboratory from René Rachou Research Center (Belo Horizonte, Brazil). Both filtered and non-filtered latex solutions were tested against young and adult B. glabrata, reared in the Malacology Laboratory, descending from snails collected in the Pampulha Lagoon (Belo Horizonte, MG) and against adult B. glabrata from the field, collected in Água Branca, municipality of Comercinho (MG). The assays were done using 10 snails at each concentration and each concentration was repeated two or three times. The diameter intervals used for the young and adults snails from the laboratory were: $2-4,5-7 \mathrm{~mm}$ (young) and $8-10,12-16,16-25 \mathrm{~mm}$ (adults). The snails from the field were adults, measuring $34-37 \mathrm{~mm}$ in diameter. The latex concentrations of E. splendens used in the assays varied from 0.1 to $1.2 \mathrm{ppm}$ (mg/l) comparing the solutions filtered and unfiltered. The snails were exposed to the various concentrations of the molluscicide for a period of $24 \mathrm{~h}$, at a temperature of $22.5 \pm 1^{\circ} \mathrm{C}$. The lethal doses $\left(\mathrm{LD}_{50}\right.$ and $\left.\mathrm{LD}_{90}\right)$ were computed by probit analysis (Finney, 1971).

\section{Results}

\subsection{Association between snail density and rainfall}

The monthly fluctuations of $B$. glabrata are shown in Figs. 1 and 2. The density of B. glabrata decreased during December 95 and January 96, the period of high rainfall. During 1996, a negative relation between the rainfall and density of snails was observed. During the months where rainfall was less than $5 \mathrm{~mm}$ (May to August), the density of snails reached a peak, both in the experimental and control streams (Figs. 1 and 2). It was not possible to establish a correlation between snail density and air or water temperature. Air temperature varied from 24 to $31^{\circ} \mathrm{C}$ and water temperature from 22 to $31^{\circ} \mathrm{C}$.

\subsection{Effects of molluscicide applications}

In the experimental stream (Fig. 1), the filtered latex solution at $12 \mathrm{ppm}$ applied on September 95 did not cause a $100 \%$ mortality among B. glabrata snails. On the other hand, in November 96, the application of the non-filtered latex solution resulted in a mortality rate of $100 \%$ among the snails collected after each application. Follow-up surveys conducted until the 14th month after the last two applications revealed no snails. In the control stream (Fig. 2), slightly fewer snails were found during the second year than during the first year, but the pattern of fluctuation was similar during the 2 years. In the experimental stream Physa sp was observed during several months, after the molluscicide applications, suggesting that 


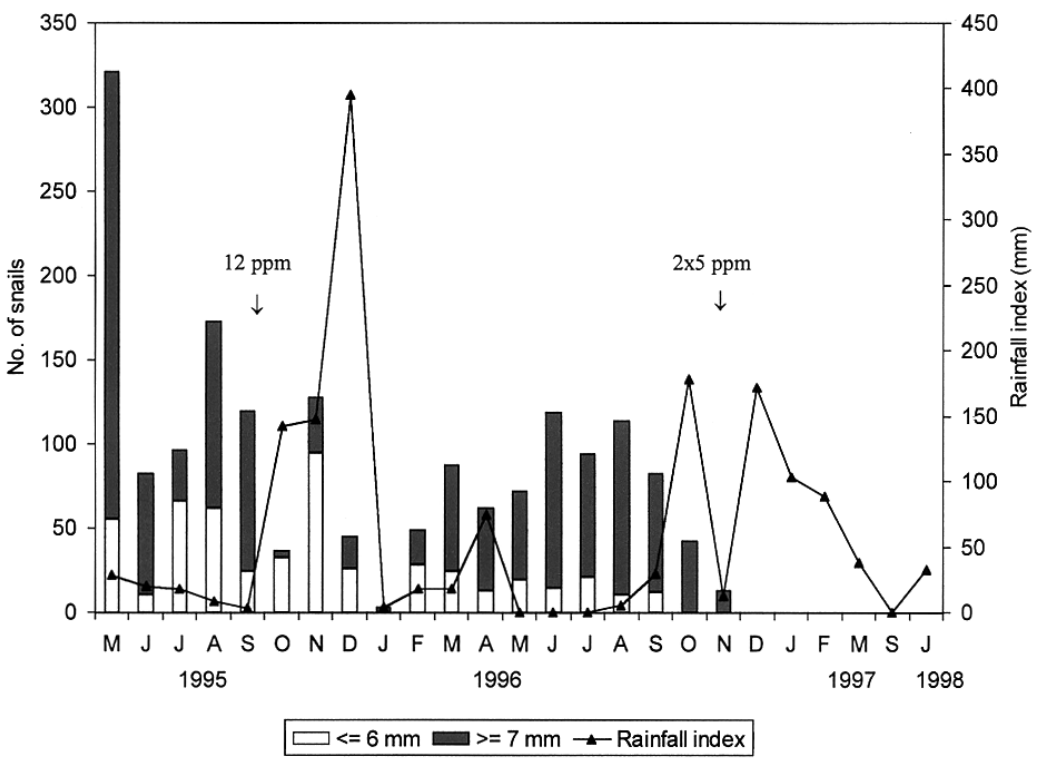

Fig. 1. Monthly fluctuations of two size classes of Biomphalaria glabrata, young ( $\leqq 6 \mathrm{~mm})$ and adults ( $\geqq 7 \mathrm{~mm})$ at the stream Córrego Barrocão, where latex of Euphorbia splendens was applied on September 1995 and November 1996, together with the rainfall $(\mathrm{mm})$.

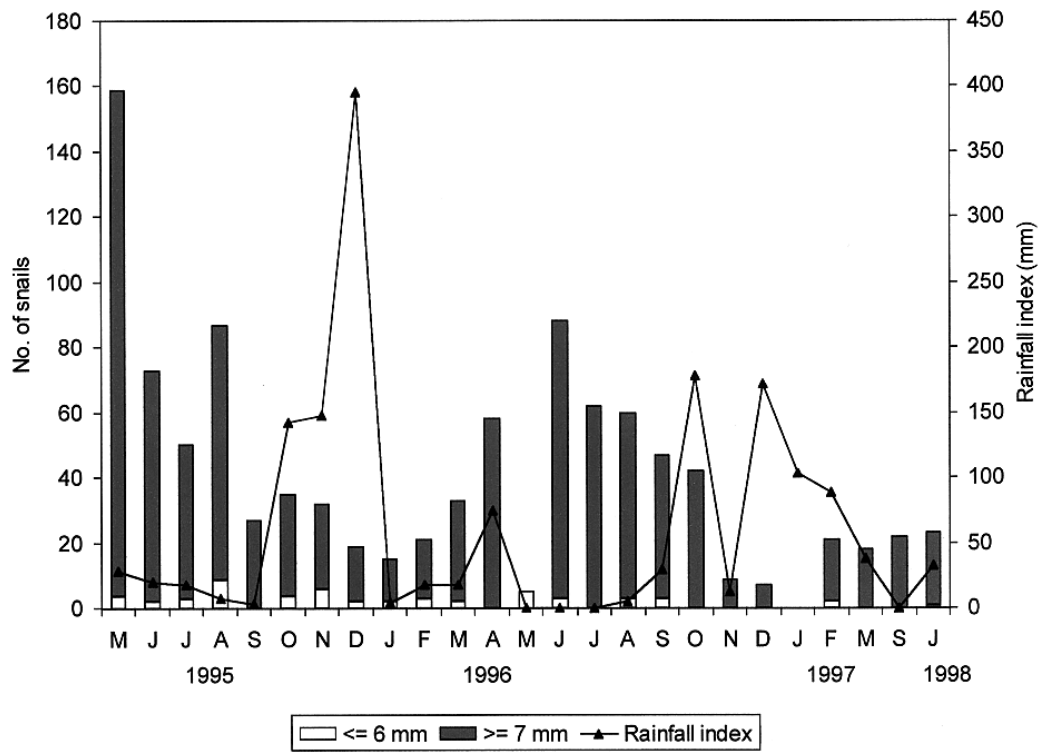

Fig. 2. Monthly fluctuations of two size classes of Biomphalaria glabrata, young( $\leqq 6 \mathrm{~mm})$ and adults ( $\geqq 7 \mathrm{~mm})$ at the stream Córrego Areia selected as untreated control, together with the rainfall $(\mathrm{mm})$. 
Table 1

Lethal concentrations $\left(\mathrm{LD}_{50}\right.$ and $\left.\mathrm{LD}_{90}\right)$ obtained in laboratory testing the latex of $E$. splendens solutions without filtration ( $\left.\mathrm{A}_{1}\right)$ and filtered $\left(\mathrm{A}_{2}\right)$, including the dose correction (d.c.)

\begin{tabular}{|c|c|c|c|c|c|}
\hline \multirow{3}{*}{$\begin{array}{l}\text { Latex sample }\left(\mathrm{A}_{1}\right) \\
\text { LLaboratory snails }\end{array}$} & \multirow{3}{*}{$\begin{array}{l}\text { Diameter of snails }(\mathrm{mm}) \\
2-04\end{array}$} & \multicolumn{2}{|l|}{$\mathrm{LD}_{50}(\mathrm{ppm})$} & \multicolumn{2}{|l|}{$\mathrm{LD}_{90}(\mathrm{ppm})$} \\
\hline & & \multicolumn{2}{|c|}{$A_{1}$ (d.c.) $A_{2}$ (d.c.) } & \multicolumn{2}{|c|}{$A_{1}$ (d.c.) $A_{2}$ (d.c.) } \\
\hline & & $0.18(0.01)^{\mathrm{a}}$ & $0.22(0.02)^{\mathrm{a}}$ & $0.32(0.03)^{\mathrm{a}}$ & $0.41(0.04)^{\mathrm{a}}$ \\
\hline & $5-07$ & $0.22(0.01)$ & $0.26(0.02)$ & $0.43(0.04)$ & $0.61(0.09)$ \\
\hline & $8-10$ & $0.19(0.01)^{\mathrm{a}}$ & $0.23(0.02)^{\mathrm{a}}$ & $0.27(0.02)^{\mathrm{a}}$ & $0.44(0.05)^{\mathrm{a}}$ \\
\hline Field snails & $34-37$ & $0.60(0.04)^{\mathrm{a}}$ & & $0.83(0.09)^{\mathrm{a}}$ & \\
\hline
\end{tabular}

${ }^{\mathrm{a}} \chi^{2}$ test $(P>0.05)$

there was limited effects of the latex on this species or that it was introduced after the applications.

\subsection{The laboratory observations (Table 1)}

Filtered latex was less toxic to B. glabrata than unfiltered latex. The unfiltered solution $\left(\mathrm{A}_{1}\right)$ presented high activity to the snails measuring up to $10 \mathrm{~mm}$ diameter and the filtered latex $\left(\mathrm{A}_{2}-\right.$ solid part) was less active than the $A_{1}$, producing variations in the lethal doses $\left(\mathrm{LD}_{90}\right)$, presumably as a result of the great heterogeneity of this last solution. The liquid part of the filtered latex $\left(A_{3}\right)$ was not active in the concentrations tested from 0.1 to $0.8 \mathrm{ppm}$.

\section{Discussion}

The present field study has shown that latex of $E$. splendens can be efficient in the control of $B$. glabrata snails using the strategy of dual applications at an interval of 15 days. This strategy kills all snails, including those that hatched after the first application; the latex is not ovicidal at the concentration used (Schall et al., 1998).

The delayed repopulation is probably related to the fact that this stream is totally isolated, without tributaries within the study area.

The present results are more important when compared with several previous studies using other molluscicide products such as niclosamide.
Despite the fact that niclosamide can exterminate snails from treated sites, late follow-up surveys have confirmed that vectors will invariably re-infest areas about a month after treatment (Khallaayoune et al., 1998; Pieri et al., 1995). As pointed out by Pieri et al. (1995), to maintain a low prevalence of schistosomiasis, niclosamide application must be repeated monthly along with treatment of infected people. This strategy is too costly and unfeasible at such intervals. Khallaayoune et al. (1998) also pointed out the necessity of a second application to prevent the rapid recolonization after the use of niclosamide. Thus, data from the present study open even wider possibilities for the use of the E. splendens latex in endemic areas in Brazil, which could be easier and of lower costs to be applied repeatedly than niclosamide. Besides this, an operational model with the participation of the community can be implemented using the structure of agricultural schools for plant cultivation, extraction and application of the latex. With this procedure, the community itself could disseminate the plant to the margins of rivers and ponds that serve as focal point of schistosomiasis transmission.

Data from Baptista et al. (1994, 1997) concerning the cost-benefit ratio of the product and the vegetative development and seed germination confirm the potential use of the plant and its large-scale culture using simple and feasible operational process. Besides this, extensive toxicological evaluation of the latex and the miliamines have been conducted and the results indicated 
that at the concentrations used in the field, as 5 or $12 \mathrm{ppm}$, there are no harmful effects to non-target organisms and the environment (Schall et al., 1998). The next step is under way in order to repeat this longitudinal field study at other endemic areas and evaluate its impact on reducing (and hopefully eradicating) the vector snails and schistosomiasis prevalence among the target population.

\section{Acknowledgements}

We are grateful to Dr. Isabela Cabral Félix de Sousa from the Laboratory of Health and Environmental Education-IOC-FIOCRUZ, for providing an English revision of the original manuscript and to Sérgio William Viana Peixoto from the Laboratory of Schistosomiasis-CPqRRFIOCRUZ, for technical assistance. This research was supported by the UNDP/World Bank/WHO Special Programme for Research and Training in Tropical Diseases, CNPq, and FIOCRUZ.

\section{References}

Andrews, P., Thyssen, J., Lorke, D., 1983. The biology and toxicology of molluscicides, Bayluscide. Pharmacol. Ther. 19, 245-295.

Baptista, D.F., Vasconcellos, M.C., Lopes, F.E.F., Silva, I.P., Schall, V.T., 1992. Evaluation of the molluscicidal property of Euphorbia splendens var. hislopii (n. E. B.) (Euphorbiaceae) - 2. Investigation in a lotic habitat. Mem. Inst. Oswaldo Cruz 87 (4), 549-553.

Baptista, D.F., Vasconcellos, M.C., Lopes, F.E., Silva, I.P., Schall, V.T., 1994. Perspectives of using Euphorbia splendens as a molluscicide in schitosomiasis control programs. Southeast Asian J. Trop. Med. Publ. Hlth 25, 419-424.

Baptista, D.F., Soares, L.H., Vasconcellos, M.C, Lopes, F.E.F., Paz, I.S., Schall, V.T., 1997. Vegetative development and seed germination of Euphorbia splendens var. hislopii, a biomolluscicidal species. Arq. Biol. Tecnol. 40 (2), 435-441.

Finney, D.J., 1971. Probit Analysis, 3rd Ed. New Delhi, Cambridge University Press, p. 333.

Khallaayoune, K., Madsen, H., Laamrani, H., 1998. Evaluation of three methods to control Bulinus truncatus, the intermediate host of Schistosoma haematobium in an irrigation scheme, Tessaout-Amont, Morocco. Acta Tropica 69, $51-63$.

McCullough, F.S., 1992. The role of mollusciciding in schistosomiasis control. WHO/Schist/92.107.

Mendes, N.M., Baptista, D.F., Vasconcellos, M.C., Schall, V.T., 1992. Evaluation of the molluscicidal properties of Euphorbia splendens var. hislopii (N. E. B.) (Euphobiaceae) 1. experimental test in a lentic habitat. Mem. Inst. Oswaldo Cruz 87 (1), 21-23.

Mendes, N.M., Vasconcellos, M.C., Baptista, D.F., Rocha, R.S., Schall, V.T., 1997. Evaluation of the molluscicidal properties of Euphorbia splendens var. hislopii (N.E.B.) Latex: Experimental test in an endemic area in the state of Minas Gerais, Brazil. Mem. Inst. Oswaldo Cruz 92 (5), 719-724

Pieri, O., Gonçalves, J.F., Sarquis, O., 1995. Repeated focal mollusciciding for snail control in sugar-cane area of northeast Brazil. Mem. Inst Oswaldo Cruz 90, 535-536.

Rocha R.S., 1995. A 18-year prospective study on morbidity due to Schistosoma mansoni in highly endemic area in the State of Minas Gerais, Brazil. Resumo 5. Simpósio Internacional de Esquistossomose, Salvador, Bahia.

Schall, V.T., Vasconcellos, M.C., Villaça-Coelho, A.L., Ferreira-Lopes, F.E., Silva, I.P., 1992. Evaluation of temporal, seasonal and geographic stability of the molluscicidal property of Euphorbia splendens latex. Rev. Inst. Med. Trop. São Paulo 34 (3), 183-191.

Schall, V.T., Vasconcellos, M.C., Souza, C.P., Baptista, D.F., 1998. The molluscicidal activity of 'crown of christ' (Euphorbia splendens var. hislopii) latex on snails acting as intermediate hosts of Schistosoma mansoni and Schistosoma haematobium. Am. J. Trop. Med. Hyg. 58 (1), 7-10.

Vasconcellos, M.C., Schall, V.T., 1986. Latex of 'coroa de cristo' (Euphorbia splendens): an effective molluscicide. Mem. Inst. Oswaldo Cruz 81 (4), 475-476.

World Health Organization, 1994. The control of schistosomiasis. WHO Tech Rep Ser 830.

Zani, C.L., Marston, A., Hamburger, M., Hostettman, K., 1993. Molluscicidal miliamines from Euphorbia milii var. hislopii. Phytochemistry 34 (1), 89-95. 